\title{
Report (1966-1970) of the Subcommittee on the Taxonomy of Staphylococci and Micrococci to the International Committee on Nomenclature of Bacteria
}

\author{
13 August 1970
}

Mexico City, Mexico

The Subcommittee met in London in April 1968 , and the principal items discussed were species and genera of gram-positive and catalase-positive cocci that should be recognized in the 8th edition of Bergey's Manual. Papers on aspects of the taxonomy of these organisms were presented at the meeting, and they have been published in the International Journal of Systematic Bacteriology. The majority of the Subcommittee favored the following classification of gram-positive and catalasepositive cocci.

Genera. Four genera should be recognized: Staphylococcus Rosenbach, Micrococcus Cohn, Planococcus Migula, and Aerococcus Williams, Hirch, and Cowan.

Species. Two species should be recognized in the genus Staphylococcus: $S$. aureus and $S$. epidermidis; $S$. aureus is the type species. Five species should be recognized in the genus Micrococcus: $M$. saprophyticus, $M$. lactis, $M$. roseus, $M$. luteus, and $M$. morrhuae; $M$. luteus is the type species. There is one species in
Planococcus, Planococcus citreus, and one species in Aerococcus, Aerococcus viridans.

Since the IXth International Congress for Microbiology (Moscow), J. B. Evans and A. C. Baird-Parker have resigned as Chairman and Secretary, respectively. A. C. Baird-Parker and M. Kocur were subsequently elected as Chairman and Secretary, respectively.

The present membership of the Subcommittee is as follows: A. C. Baird-Parker (Chairman), Bedford, England; M. Kocur (Secretary), Brno, Czechoslovakia; J. B. Evans, Raleigh, North Carolina, USA; R. H. Deibel, Madison, Wisconsin, USA; T. Gibson, Edinburgh, Scotland; L. Grün, Düsseldorf, Germany; L. R. Hill, London, England; D. A. A. Mossel, Zeist, the Netherlands; P. Oeding, Bergen, Norway; and A. Torres Pereira, Lisbon, Portugal.

The next meeting of the Subcommittee will be held in April or May of 1971 at either Brno, Czechoslovakia, or London, England.

M. Kocur, Secretary

A. C. Baird-Parker, Chairman 